open book and every piece of common ground a treasury of interest. At all times his heart was responsive to the beauty around him. Plants became the song-the music-of his life, and through his long and intimate study of them he found that order, meaning and harmony was the foundation of all nature.

No reader or listener could help catching Mr. Budd's enthusiasm as he described the Spring Beauty blooming in the Cypress Hills before the snow was altogether gone, or the difference that he had discovered between two types of seed produced on a single plant of Russian pigweed: one oval and winged, germinating readily; the other round and wingless with a long period of dormancy. Mr. Budd considered both the lilies of the field and the weeds which pose so serious a problem for the farmer.

His was no easy life, but hard work and disappointments he took without murmur. Looking back over the years and seeing the fulfilment of his early dreams his heart was full of gratitude for all that his new country had meant to him.

Readers of the Blue Jay will miss his name on the pages which have been enriched and adcrned by his articles and drawings for so many years. He will continue to be missed at the SNHS annual meetings. He has left a lonely place in the hearts of all who were privileged to know him, this humble student of the wonders of nature.

\title{
Records of Saskatchewan Fern Species in the Qu'Appelle Valley
}

\author{
by Bernard de Vries, Box 342, Fort Qu'Appelle
}

This is a brief annotated list of four fern species collected in the Qu'Appelle Valley and its tributary coulees during 1959 and 1960 , with indications of where each collection was made. Fifteen collections are described.

The sequence of families and genera follows M. L. Fernald, 1950, Gray's Manual of Botany, and $H$. J. Scoggan, 1957, Flora of Manitoba. The numbers cited refer to collections in my herbarium. With certain exceptions, duplicates are in the herbaria of the Division of Botany and Plant Pathology, Canada Department of Agriculture, Ottawa, and the Saskatchewan Museum of Natural History, Regina. These herbaria are indicated by the symbols DAO and SMNH.

Determinations were checked by Dr. Bernard Boivin of the Research Branch, Canada Department of Agriculture, Ottawa. I should like to extend my sincere thanks to Dr. Boivin for his kindly help and encouragement. I am also thankful to $\mathrm{Mr}$. $\mathrm{H}$. Kelly of Tantallon and to $\mathrm{Mr}$. and Mrs. F. Swanson of Whitewood, whose intimate knowledge and inter- est in their localities gave me access to interesting areas.

The writer hopes to add to this list as he continues his research in the ecology of the vegetation of the Qu'Appelle Valley, and would appreciate learning of any additional locations or species of fern in this part of Saskatchewan.

\section{OPHIOGLOSSACEAE}

Botrychium lunaria (L.) Sw., Moonwort. 752. Immature sterile and fertile bliades. Moist, richly-wcoded coulee. Rare. Associated flora: Populus balsamifera, Acer negundo var. interius, Aquilegia canadensis var. eminens, Linnaea borealis var. americana, Viburnum lentago, Bryum pseudotriquetreum. East of Tantallon, June 30, 1960.

Botrychium virginianum (L.) Sw., Rattlesnake-Fern. 222. Mature fertile and sterile fronds. Moist, denselywooded area. Near rich stand of Ostrich-Fern. Uncommon. Assoaiated flora: Populus balsamifera, Actaea rubra including forma neglecta, Viburnum trilobum. One mile north of Crooked Lake, July 27, 1959. 
-351. DAO. Mature siterile frond, fertile blade absent. Moist, richlywooded cculee. Near small stand of Ostrich-Fern. Uncommon. Associated flora: Populus balsamifera, Quercus macrocarpa (on slope), Aquilegia canadensis var. eminens, Pruilus virginiana, Bryum pseudotriquetrum. Elast of Tantallon, August $3,1959$.

-269. Mature sterile frond, fertile blade absent. Open woods in coulee. Not common. Associated flora: Populus tremuloides, Salix sp., Cornus americana, Pyrola. secunda, Equisetum arvense. Easit of Craven, August 19, 1959.

-751. DAO. SMNH. Mature sterile fronds, immature fertile bladie, Moist woods, in shaded coulee. Noit common. Associated flora: Populus balsamifera, Acer negundo var. interius, Viburnum lentago, Pyrola secunda. Cutarm Valley, easit of Tantallon, June 30, 1960.

-922. Mature sterile frond and fertile blades. Moist woods in shaded coulee, near margin of boggy meadow. Not common. Associarted flora: Populus balsamifera, Salix sp., Parnassia palustris var. neogaea, Lobelia kalmii. Springcreek Coulee, north of Crooked Lake, August 26, 1960.

\section{POLYPODIACEAE}

Cystopteris fragilis (L.) Bernh., Fragile Fern. 270. DAO. Immature fronds, sporangia absent. Moist woods. Near small stand of OstrichFern. Not common. Associated flora: Populus balsamifera, Acer negundo var. interius, Caltha palustris, Brachythecium sp. (sterile). East of Tantallon, Augusit 3, 1959.

-825. DAO. SMNH. Marure, Extensive stand along stream in heavily grazed open habitait, under Salix discolor. Associated floma: Salix sp., Amelanchier alnifolia, Primula incana. North of Bridgeford, July 20, 1960.

Matteuccia struthiopteris (L.) Tood. var. pensylvanica (Willd.) Monton, Ostrich-Ferm, 232. DAO. SMNH. Mature sterile fronds, immature fertile frond. Fertile fronds from previous year still present with sporangia. Woods, damp soil subject to spring flooding. Large stand. Associated flora: Populus balsamifera, Acer negundo var. interius, Mnium affine. Six miles east of Crooked Lake, July 27, 1959.

-252. Mature siterile fronds, fertile fronds absent. Moist, richlywooded coulee on sandy soil along stream. Extensive stand. Associated flora: Populus balsamifera, Acer negundo var. interius, Actaea rubra including forma neglecta, Mnium affine, Conocephalum conicum. South shore of Round Lake, Augusit 2, 1959.

-248. DAO. SMNH. Mature sterile fronds, fertile fronds absent. Open wooded coulee, on dry grassy hummocks subject to spring flooding. Common. Suffering from drought. Habitat altered by landslide. Associated flora: Salix spp., Populus tremuloides, Carex rostratá, Mnium affine. Two miles north of cement bridge, halif way between Round and Crooked Lakes, August 2, 1959.

-259. DAO. SMNH. Miature siterile and fertile frond. Moist wooded coulee. Smaill stand along stream. Associated flora: Populus balsamifera, Acer negundo var. interius, Botrychium virginianum, Aquilegia canadensis var. eminens; Brachythecium sp. (sterile), Bryum pseudotriquetrum. East of Tantallon, August $3,1959$.

-172. DAO. SMNH. Mature sterile and immature fertile fronds. Moist woods in deep coulee. Small stand near stream. Associated flora: Populus balsamifera, Acer negundo var. interius, Mertensia paniculata, Pyrola secunda. Bear Creek, east of Tantallon, August 3, 1959.

-358. DAO. SIMNH. Mature sterile, immature fertile fronds. Open wooded coulee, on damp alluvial soil near intermittent stream. Small partly damaged stand. Associated flora: Populus tremuloides, Viburnum trilobum, Acer negundo var. interius, Prunus virginianum, Viola rugulosa. South shore of Katepwa Lake, August 24, 1959.

-862. DAO. SIMNH. Mature sterile fronds, fertile fronds absent. Moist wooded area, near margins of stream. Extensive stand. Associated flora: Populus balsamifera, Acer negundo var. interius, Ribes americanum, Viburnum trilobum, Parnassia palustris var. neogaea. Shore of Crooked Lake, July 29, 1960. 